\title{
Nitric oxide levels in chronic liver disease patients with and without oesophageal varices
}

\author{
Assem M. El-Sherif - Mohamed A. Abou-Shady • \\ Ashraf M. Al-Bahrawy • Reda M. Bakr • \\ Abdel-Moneim M. Hosny
}

Received: 31 January 2008/ Accepted: 21 March 2008/Published online: 22 April 2008

(C) The Author(s) 2008

\begin{abstract}
Introduction Patients with chronic liver disease ultimately progress to develop cirrhosis and portal hypertension. Recently it seems well established that nitric oxide disturbances play a key role in the pathogenesis of chronic liver disease and portal hypertension. The aim of this work was to clarify the correlation between chronic liver disease stages, liver function status, esophageal varices presence and nitric oxide disturbances. Subjects and methods All subjects $(n=120)$ in the present study were classified into; group I which included 15 age and sex matched healthy volunteers (taken as control), group II which included 20 patients with chronic active hepatitis, and group III which included 85 patients with hepatic cirrhosis. All subjects included were subjected to full clinical assessment, routine laboratory investigations, serum nitrate level determination using colorimetric method, abdominal ultrasonography and upper endoscopy. Results Increased serum nitrate level could not be detected in patients with chronic active hepatitis as well as those with early cirrhosis (Child's class A). Progressive and significant increase of serum nitrate levels were detected in more advanced stages of cirrhosis (Child's class $\mathrm{B} \& \mathrm{C}$ ). The best non-invasive predictor for the presence of oesophageal varices was a combination of platelet count $<150.000 / \mathrm{mm}^{3}$, splenomegaly $>18 \mathrm{~cm}$, Child's class $\mathrm{B}$ or $\mathrm{C}$ and serum nitrate $\geq 38 \mu \mathrm{mol} / \mathrm{l}$, with
\end{abstract}

\footnotetext{
A. M. El-Sherif · M. A. Abou-Shady · A. M. Al-Bahrawy ( $₫)$. R. M. Bakr

Internal Medicine Department, Al-Azhar Faculty of Medicine, Nasr City, Cairo, Egypt

e-mail: bahrawy3@hotmail.com

URL: http://www.azharmed.edu.eg/home.htm
}

A.-M. M. Hosny

Clinical Pathology Department, Al-Azhar Faculty of Medicine,

Nasr City, Cairo, Egypt
93.3\% sensitivity and $100 \%$ specificity. Conclusion Serum nitrate level can be used as a non-invasive predictor for progression of chronic liver disease as well as for the presence of oesophageal varices.

Keywords Chronic liver disease $\cdot$ Nitric oxide . Oesophageal varices

\section{Introduction}

Chronic active hepatitis and cirrhosis are classified as chronic liver diseases. Chronic liver diseases may be accompanied by portal hypertension. Liver cirrhosis with portal hypertension is characterized by several systemic and splanchnic hemodynamic changes [1]. Within the splanchnic and systemic circulation, there is increased cardiac output and hyperdynamic circulation that contribute to increased flow into the portal circulation, thereby perpetuating portal hypertension [2]. Vascular remodeling and angiogenesis occur at the portosystemic interface so as to relieve the resulting excess portal pressure and allow decompression by redistributing flow through esophageal collaterals. Unfortunately, the resulting generation of varices is a major contributor to morbidity and mortality [2].

Increased serum nitric oxide (NO) levels in patients with cirrhosis have been reported repeatedly [3, 4]. A previous Egyptian study indicated an association between the NO levels and the development and progression of liver cirrhosis [5]. NO system disturbances seem to play a key role in the pathogenesis of chronic liver disease and are proposed as one of the major endogenous vasodilators in portal hypertension $[6,7]$. It is also thought to be the cause of some complications associated with end-stage liver disease [8]. 
The aim of this work was to clarify the correlation between liver disease stages, liver function status, oesophageal varices $(\mathrm{OV})$ extent, and the serum nitrate levels.

\section{Patients and methods}

This study was conducted between August 2005 and August 2006 in Al-Azhar University Hospital. One hundred and twenty persons (90 men and 30 women) were included and classified into 3 groups. Group I, which included 15 (10 men and 5 women) age- and sex-matched volunteers was taken as controls. Their age ranged from 30 to 59 years. Group II included 20 (13 men and 7 women) patients with chronic active hepatitis. Their age ranged from 32 to 56 years. Group III included 85 (67 men and 18 women) patients with hepatic cirrhosis. Their age ranged from 31 to 60 years. Cirrhotic patients (group III) were subdivided into A $(n=25), \mathrm{B}(n=30)$, and $\mathrm{C}(n=30)$ according to Child's classification.

Chronic active hepatitis and cirrhosis were diagnosed by clinical, biochemical, ultrasound, and/or histological criteria. The causes of chronic liver disease in our patients were attributed to HCV $(n=64)$, HBV $(n=46)$, and both HCV and HBV $(n=10)$. The patients were not under specific treatment for their liver diseases or vasoactive drugs during the study. Patients with hepatosplenic schistosomiasis, hepatocellular carcinoma, portal vein thrombosis, cardiac failure, renal failure, respiratory failure, and other chronic diseases, patients consuming relevant amounts of alcohol, and pregnant women were excluded from the study. Patients with excess dietary nitrite/nitrate intake were excluded, and standardized diet was not used.

Standard commercial photometric assays for alanine aminotransferase, aspartate aminotransferase, serum bilirubin, serum albumin, prothrombin time, and INR were performed in all persons $(n=120)$. Diagnosis of both $\mathrm{HBV}$ and $\mathrm{HCV}$ was based on $\mathrm{HBsAg}, \mathrm{HBcAb}$, and $\mathrm{HCVAb}$ tests by ELISA technique using DiaSorin kits (Italy). For serum nitrate testing, fasting blood samples were taken from both patients and control groups at 9 a.m. Venous samples were collected in a serum separator tube, and then centrifuged; finally, serum was removed and stored at $-20^{\circ} \mathrm{C}$ or below until it was analyzed. All samples were diluted at least 2 -fold into reduction buffer. After dilution, samples were subjected to ultrafiltration through a 10,000-molecular weight cutoff filter to remove high molecular weight proteins. NO metabolites were measured by using BLOXYTECH nitric oxide assay (colorimetric assay). The resulting values were given as $\mu \mathrm{mol} / 1$ nitrate (normal nitrate value $=0-30 \mu \mathrm{mol} / \mathrm{l}$ ).

For hepatic and splenic span measurements, hepatic texture evaluation, portal and hepatic venous systems assessment, and detection of ascites, all patients $(n=120)$ were subjected to abdominal ultrasonography. According to the longitudinal axis of the spleen, splenomegaly may be of the following types: mild $(13-15 \mathrm{~cm})$, moderate $(16-$ $18 \mathrm{~cm})$, and massive $(>18 \mathrm{~cm})$. In the presence of ascites, it is graded as mild, moderate, and marked on basis of ultrasonography.

For detection and grading of $\mathrm{OV}$, all persons were subjected to upper endoscopy. All endoscopies were performed in a single endoscopy unit using a video endoscope, and $\mathrm{OV}$ were classified according to the same criteria. $\mathrm{OV}$ were classified using the small and large classification, where small $O V$ are defined as varices that flatten with insufflation or minimally protrude into the oesophageal lumen, whereas large $O V$ were defined as varices that protrude into the oesophageal lumen and touch each other or fill at least $50 \%$ of the oesophageal lumen.

Patients with chronic liver disease and compensated liver function $(n=45)$ were subjected to percutaneous transthoracic ultrasound-guided liver biopsies for the separation of chronic active hepatitis and Child's class "A" cirrhosis.

The statistical analysis of data was performed using SPSS software statistical computer package, Version 10. Comparison between the groups was made with the Student $t$ test for unpaired data. Analysis of variance was performed to test the statistical significant difference between more than 2 means. All results were expressed as mean \pm SD. Correlation coefficient $r$ was measured to test a positive or a negative linear relation between 2 variables. Chi-square analysis was performed as a test of significance. Result was considered significant if $P<0.05$ and highly significant if $P<0.01$.

\section{Results}

No significant difference was reported among all groups either in age or in sex distribution $(P>0.05)$. Patients with advanced liver disease (Child's class B or C) were significantly hypotensive and had higher heartrate $(P<0.01)$. There was no significant correlation between nitrate levels and age or sex distributions $(P>0.05)$. In contrast, a highly significant positive correlation was reported between serum nitrate levels and pulse rate $(r=0.36)$, jaundice $(r=0.38)$, hepatic encephalopathy $(r=0.69)$, and lower limb edema $(r=0.62)(P<0.01)$. Also, a highly significant negative correlation was found with mean arterial blood pressure $(r=-0.42)(P<0.01)$. The correlation between serum nitrate levels and the laboratory investigations in the studied groups revealed a highly significant negative correlation with white blood cells count ( $r=-0.47)$, hemoglobin concentration $(r=-0.6)$, and 
platelet count $(r=-0.63)(P<0.01)$. Although a highly significant negative correlation was found between serum nitrate levels and serum albumin $(r=-0.72)(P<0.01)$, a highly significant positive correlation was reported with serum bilirubin $(r=0.58)$ and INR values $(r=0.6)$ $(P<0.01)$. The difference between serum nitrate levels in $\mathrm{HCV}$ and HBV chronic liver disease patients was statistically insignificant.

A highly significant positive correlation was found for serum nitrate levels with spleen size $(r=0.67)$ and ascites grade $(r=0.77)(P<0.01)$. A highly significant positive correlation was observed between serum nitrate levels and necroinflammatory grades $(r=0.48) \quad(P<0.01) \quad$ and fibrosis stages $(r=0.6)(P<0.01)$.

In comparison to the control group, patients with chronic active hepatitis had no significant increase in serum nitrate levels $(P=0.711)$. In comparison to the control group and patients with chronic active hepatitis, Child's class "A" patients had no significant increase in serum nitrate levels. In Child's class "B" patients, a highly significant increase in serum nitrate levels was observed compared with Child's class "A" patients $(P<0.001)$. In addition, a highly significant increase in serum nitrate levels was observed in Child's class " $\mathrm{C}$ " patients compared with Child's class "B" patients $(P<0.001)$ (Table 1).

A highly significant difference was found between serum nitrate levels in cirrhotic patients without $\mathrm{OV}$ and those with small OV $(P<0.01)$. Also, a highly significant increase in serum nitrate levels was found in cirrhotic patients with large OV compared with cirrhotic patients without OV $(P<0.01)$ (Table 2). Comparing the serum nitrate levels among different grades of $\mathrm{OV}$ in the same Child's class, a highly significant positive correlation was found between serum nitrate levels and $\mathrm{OV}$ grades (Table 3).

The lower cutoff level of serum nitrate below which large OV could not be detected in cirrhotic patients was $73 \mu \mathrm{mol} / \mathrm{l}$. The best cutoff level of serum nitrate for prediction of $\mathrm{OV}$ in cirrhotic patients was $38 \mu \mathrm{mol} / \mathrm{l}$. It had

Table 1 Mean values of serum nitrate level in chronic liver disease patients in comparison with control

\begin{tabular}{llllc}
\hline Group & Number & Mean nitrate $\pm \mathrm{SD}$ & $t$ & $P$ \\
\hline Control & 15 & $34.44 \pm 3.17$ & & \\
CAH & 20 & $34.15 \pm 1.39$ & 0.37 & 0.7119 \\
Child's A & 25 & $35.74 \pm 12.18$ & 0.40 & 0.6890 \\
Child's B & 30 & $57.05 \pm 22.01$ & 3.94 & $<0.01^{*}$ \\
Child's C & 30 & $89.25 \pm 22.21$ & 9.46 & $<0.001^{*}$ \\
\hline
\end{tabular}

$\mathrm{CAH}=$ Chronic active hepatitis, $*$ highly significant result
$86.5 \%$ sensitivity, $83.3 \%$ specificity, $95 \%$ positive predictive value, and $62.5 \%$ negative predictive value. Different combinations of clinical, laboratory, and sonographic variables were suggested to improve the performance of serum nitrate level $(\geq 38 \mu \mathrm{mol} / \mathrm{L})$ in the prediction of OV. The best predictive formula was a combination of platelet count $<150,000 / \mathrm{mm}^{3}$, splenomegaly $>18 \mathrm{~cm}$, Child's class $\mathrm{B}$ or $\mathrm{C}$, and serum nitrate level $\geq 38 \mu \mathrm{mol} / \mathrm{L}$, which had the highest sensitivity (93.3\%) and specificity (100\%) (Table 4).

\section{Discussion}

An increased serum nitrate level because of a metabolite of NO was demonstrated in patients with chronic liver diseases [9]. Also the level of nitrate could be correlated with Child-Pugh classes in cirrhotic patients [10]. Previous studies $[9,11]$ reported higher nitrate concentration in patients with chronic hepatitis. We did not find any significant difference between nitrate levels in patients with chronic active hepatitis and healthy controls. This was consistent with Parvu et al. [10] and Arkenau et al. [4]. A possible explanation is that the differences in the severity of inflammation and fibrosis may cause varying serum nitrate levels, and the etiology of chronic hepatitis may explain the discrepancy between some previously reported studies and our results. Cirrhosis is considered as the most advanced stage of chronic liver disease. In viral cirrhosis, there is a significant increase in the serum nitrate [12-15]. In our study, the nitrate concentration was significantly increased in advanced degrees of cirrhosis (B and C). Also nitrate level was correlated with Child's classes.

Several complications are related to liver cirrhosis, including the development of variceal hemorrhage. Variceal hemorrhage is a consequence of portal hypertension that develops in cirrhosis both because of an increase in splanchnic blood flow secondary to vasodilatation within the splanchnic vascular bed and because of increased resistance to the passage of blood through the liver. NO may play a critical role by promoting both collateral flow through dilatation of pre-existing vessels and vascular remodeling and angiogenesis [16-18]. In advanced cirrhosis, nitrate levels can be correlated to complications of portal hypertension [4, 9, 19-22]. Arkenau et al. [4] established the connection between the extent of portal hypertension and nitrate levels, whereas the progression of $\mathrm{OV}$ was associated with higher circulating nitrate levels. According to our results, higher nitrate levels were observed in cirrhotic patients with OV. Also, good correlations were found between nitrate levels in cirrhotic patients and OV grades. 
Table 2 Mean values of serum nitrate levels in relation to oesophageal varices grades

Highly significant result

\begin{tabular}{llrlllll}
\hline Oesophageal varices grade & $\begin{array}{l}\text { Number of } \\
\text { patients }(\mathrm{n}=85)\end{array}$ & Mean nitrate $\pm \mathrm{SD}$ & $\mathrm{t}$ & $P$ & ANOVA & $P$ \\
& & & & & \\
\hline No oesophageal varices & 10 & $36.6 \pm 7.85$ & - & - & 478.16 & $<0.001^{*}$ \\
Small oesophageal varices & 43 & $51.04 \pm 11.5$ & 4.43 & $<0.001^{*}$ & & \\
Large oesophageal varices & 32 & $109.25 \pm 3.54$ & 28.72 & $<0.001^{*}$ & &
\end{tabular}

Table 3 Mean values of nitrate levels in cirrhotic patients in relation to Child's classes and oesophageal varices grades

\begin{tabular}{|c|c|c|c|c|c|c|}
\hline \multirow[t]{2}{*}{ Oesophageal varices grades } & \multicolumn{2}{|c|}{ Child class A } & \multicolumn{2}{|c|}{ Child class B } & \multicolumn{2}{|c|}{ Child class $\mathrm{C}$} \\
\hline & Number & $\begin{array}{l}\text { Mean nitrate } \\
(\mu \mathrm{mol} / \mathrm{l}) \pm \mathrm{SD}\end{array}$ & Number & $\begin{array}{l}\text { Mean nitrate } \\
(\mu \mathrm{mol} / \mathrm{l}) \pm \mathrm{SD}\end{array}$ & Number & $\begin{array}{l}\text { Mean nitrate } \\
(\mu \mathrm{mol} / \mathrm{l}) \pm \mathrm{SD}\end{array}$ \\
\hline No oesophageal varices & 7 & $30.17 \pm 0.66$ & 3 & $35.93 \pm 2.96$ & 0 & 0 \\
\hline Small oesophageal varices & 16 & $39.8 \pm 1.31$ & 18 & $52.53 \pm 2.12$ & 9 & $68.8 \pm 1.23$ \\
\hline Large oesophageal varices & 2 & $74.1 \pm 1.56$ & 9 & $104.67 \pm 2.6$ & 21 & $110.96 \pm 1.89$ \\
\hline ANOVA & & 29.99 & & 65.15 & & 102.62 \\
\hline$P$ & & $<0.001 *$ & & $<0.001 *$ & & $<0.001^{*}$ \\
\hline
\end{tabular}

* Highly significant result

Table 4 Noninvasive Predictors of oesophageal varices in cirrhotic patients

\begin{tabular}{|c|c|c|c|c|}
\hline Noninvasive predictors & $\begin{array}{l}\text { Sensitivity } \\
(\%)\end{array}$ & $\begin{array}{l}\text { Specificity } \\
(\%)\end{array}$ & $\begin{array}{l}\text { PVP } \\
(\%)\end{array}$ & $\begin{array}{l}\text { PVN } \\
(\%)\end{array}$ \\
\hline Platelet count $<150.000 / \mathrm{mm}^{3}$ & 60.5 & 88.4 & 70 & 87 \\
\hline Platelet count $<150.000 / \mathrm{mm}^{3}+$ nitrate level $\geq 38 \mu \mathrm{mol} / \mathrm{l}$ & 65.2 & 89.1 & 74 & 95 \\
\hline Platelet count $<150.000 / \mathrm{mm}^{3}+$ splenomegaly $>18 \mathrm{~cm}$ & 72.9 & 94.3 & 83 & 81.1 \\
\hline Platelet count $<150.000 / \mathrm{mm}^{3}+$ nitrate level $\geq 38 \mu \mathrm{mol} / 1+$ splenomegaly $>18 \mathrm{~cm}$ & 74.1 & 95.1 & 87.2 & 86 \\
\hline Platelet count $<150.000 / \mathrm{mm}^{3}+$ splenomegaly $>18 \mathrm{~cm}+$ Child's class B/C & 85.1 & 100 & 100 & 93.9 \\
\hline Nitrate level $\geq 38 \mu \mathrm{mol} / \mathrm{l}$ & 86.5 & 83.3 & 95.8 & 62.5 \\
\hline $\begin{array}{l}\text { Platelet count }<150.000 / \mathrm{mm}^{3}+\text { nitrate level } \geq 38 \mu \mathrm{mol} / 1+\text { splenomegaly }>18 \mathrm{~cm}+\text { Child's } \\
\text { class } \mathrm{B} / \mathrm{C}\end{array}$ & 93.3 & 100 & 100 & 94.2 \\
\hline
\end{tabular}

Predictive value positive $=\mathrm{PVP}$, Predictive value negative $=\mathrm{PVN}$

Taking into account these results, we examined the value of nitrate levels as a noninvasive screening tool for the presence of $\mathrm{OV}$ in cirrhotic patients. The noninvasive assessment of the presence/absence of OV implies a series of medical and social issues [23]. In fact, from a medical point of view, such a noninvasive approach has to fulfill some well-defined characteristics that allow us to identify patients with $\mathrm{OV}$ and enable us to concentrate on those who are most likely to have OV. In particular, the accuracy of such noninvasive approach must represent the best compromise between the risk of missing an important diagnosis, such as OV, and lack of clinical usefulness because of the low specificity of the screening tool [28]. More accurately, such parameters should be directly related to the pathomechanisms of OV, have lower cutoff levels below which the presence of OV could be excluded, and have good correlation with different OV grades.

Platelet count, spleen size, and Child's class were the most frequently explored noninvasive parameters in the previous studies [24-28]. Although such parameters showed good sensitivity and specificity, 2 problems are encountered. On one hand, it has no cutoff value below which the presence of OV should be excluded. On the other hand, none of these parameters are directly related to the pathomechanisms of $\mathrm{OV}$; instead all of them are complications of portal hypertension and liver dysfunction that can precede, follow, or occur simultaneously with OV. Two recent studies $[28,29]$ addressed the first problem through expressing the platelet/spleen size and right liver lobe/albumin ratios that can accurately determine the presence of OV. Here we report a parameter directly related to the pathomechanisms of $\mathrm{OV}$, has a lower cutoff level below which the presence of OV could be excluded, and has good correlation with different OV grades. Elevated serum nitrate level predicts $\mathrm{OV}$ in cirrhotic patients with reasonable sensitivity and specificity, as well as it has positive correlation with OV grades. The addition of low platelet count, splenomegaly, and advanced Child's classes 
significantly improve the serum nitrate sensitivity (93.3\%) for prediction of $\mathrm{OV}$.

\section{Conclusion}

Serum nitrate levels can be used as a noninvasive predictor for progression of chronic liver diseases and the presence of OV. A large number of study subjects are needed for further validation of these results.

Open Access This article is distributed under the terms of the Creative Commons Attribution Noncommercial License which permits any noncommercial use, distribution, and reproduction in any medium, provided the original author(s) and source are credited.

\section{References}

1. Liu H, Gaskari SA, Lee SS. Cardiac and vascular changes in cirrhosis: pathogenic mechanisms. World J Gastroenterol. 2006; 12:837-42.

2. Langer DA, Shah VH. Nitric oxide and portal hypertension: Interface of vasoreactivity and angiogenesis. $\mathbf{J}$ Hepatol. 2006;44:209-16.

3. Moriyama A, Masumoto A, Nanri H, Tabaru A, Unoki H, Imoto I, Ikeda M, Otsuki M. High plasma concentrations of nitrite/ nitrate in patients with hepatocellular carcinoma. Am J Gastroenterol. 1997;92:1520-3.

4. Arkenau HT, Stichtenoth DO, Frolich JC, Manns MP, Boker KH. Elevated nitric oxide levels in patients with chronic liver disease and cirrhosis correlate with disease stage and parameters of hyperdynamic circulation. Z Gastroenterol. 2002;40:907-13.

5. Hassan MI, Kassim SK, Ali HS, Sayed el-DA, Khalifa A. Evaluation of nitric oxide (NO) levels in hepatitis $\mathrm{C}$ virus (HCV) infection: relationship to schistosomiasis and liver cirrhosis among Egyptian patients. Dis Markers. 2002;18:137-42.

6. Vallance P, Moncada S. Hyperdynamic circulation in cirrhosis: a role for nitric oxide? Lancet. 1991;337:776-8.

7. Sogni P, Moreau R, Gadano A, Lebrec D. The role of nitric oxide in the hyperdynamic circulatory syndrome associated with portal hypertension. J Hepatol. 1995;23:218-24.

8. Elsing C, Harenberg S, Stremmel W, Herrmann T. Serum levels of soluble Fas, nitric oxide and cytokines in acute decompensated cirrhotic patients. World J Gastroenterol. 2007;13:421-5.

9. Kirkali G, Gezer S, Umur N, Ozcan MA, Tankurt E. Nitric Oxide in chronic liver disease. Turk J Med Sci. 2000;30:511-5.

10. Pâryu AE, Negrean V, Pleca-Manea1 L, Cosma A, Drãghici A, Uifãlean A, Moldovan R. Nitric Oxide in patients with chronic liver diseases. Rom J Gastroenterol. 2005;14:225-30.

11. Martin PY, Gines P, Schrier RW. Nitric oxide as a mediator of hemodynamic abnormalities and sodium and water retention in cirrhosis. NEJM. 1998;339:533-41.

12. Schweyer S, Mihm S, Radzun HJ, Hartmann H, Fayyazi A. Liver infiltrating $\mathrm{T}$ lymphocytes express interferon gamma and inducible nitric oxide synthase in chronic hepatitis $\mathrm{C}$ virus infection. Gut. 2000;46:255-9.
13. Kandemir O, Polat A, Kaya A. Inducible nitric oxide synthase expression in chronic viral hepatitis and its relation with histological severity of disease. J Viral Hepat. 2002;9:419-23.

14. Moussa YI, Plevris JN, Hyes PC. Plasma nitrites/nitrate in HCV infection and hepatocellular carcinoma. Eur J Gastroentrol Hepatol. 2000;12:159-63.

15. de Lucas S, Bartolome J, Amaro MJ, Carreno V. Hepatitis C virus core protein transactivates the inducible nitric oxide synthase promoter via NF-kappa B activation. Antiviral Res. 2003;60:117-24.

16. Fernandez M, Vizzutti F, Garcia-Pagan JC, Rodes J, Bosch J. Anti-VEGF receptor-2 monoclonal antibody prevents portalsystemic collateral vessel formation in portal hypertensive mice. Gastroenterology. 2004;126:886-94.

17. Morales-Ruiz M, Jimenez W. Neovascularization, angiogenesis, vascular remodeling in portal hypertension. In: Sanyal AJ, Shah $\mathrm{VH}$, editors. Portal hypertension: pathobiology, evaluation and treatment. Totowa NJ: humana press; 2005. p. 99-112.

18. Duda DG, Fukumura D, Jain RK. Role of eNOS in neovascularization: NO for endothelial progenitor. Trends Mol Med. 2004;10:143-5.

19. Bosch J, Garcia-Pagan JC. Complications of cirrhosis. I. Portal hypertension. J Hepatol. 2000;32(1 Suppl):141-6.

20. Wattanasirichaigoon S, Gordon FD, Resnick RH. Hyperdynamic circulation in portal hypertension: a comparative model of arterio-venous fistula. Med Hypotheses. 2000;55:77-87.

21. Moller S, Henriksen JH. Cirrhotic cardiomyopathy: a pathophysiological review of circulatory dysfunction in liver disease. Heart. 2002;87:9-15.

22. Barak N, Zemel R, Ben-Ari Z, Braun M, Tur-Kaspa R. Nitric oxide metabolites in decompensated liver cirrhosis. Dig Dis Sci. 1999;44:1338-41.

23. de Franchis R, Dell'Era A, Iannuzzi F. Diagnosis and treatment of portal hypertension. Dig Liver Dis. 2004;36:787-98.

24. Zaman A, Hapke R, Flora K, Rosen HR, Benner K. Factors predicting the presence of oesophageal or gastric varices in patients with advanced liver disease. Am J Gastroenterol. 1999;94:3292-6.

25. Ng FH, Wong SY, Loo CK, Lam KM, Lai CW, Cheng CS. Prediction of oesophagogastric varices in patients with liver cirrhosis. J Gastroenterol Hepatol. 1999;14:785-90.

26. Chalasani N, Imperiale TF, Ismail A, Sood G, Carey M, Wilcox CM, Madichetty H, Kwo PY, Boyer TD. Predictors of large oesophageal varices in patients with cirrhosis. Am J Gastroenterol. 1999;94:3285-91.

27. Giannini E, Botta F, Borro P, Risso D, Romagnoli P, Fasoli A, Mele MR, Testa E, Mansi C, Savarino V, Testa R. Platelet count/ spleen diameter ratio: proposal and validation of a non-invasive parameter to predict the presence of oesophageal varices in patients with liver cirrhosis. Gut. 2003;52:1200-5.

28. Giannini EG, Botta F, Borro P, Dulbecco P, Testa E, Mansi C, Savarino V, Testa R. Application of the platelet count/spleen diameter ratio to rule out the presence of oesophageal varices in patients with cirrhosis: a validation study based on follow-up. Dig Liver Dis. 2005;37:779-85.

29. Alempijevic T, Bulat V, Djuranovic S, Kovacevic N, Jesic R, Tomic D, Krstic S, Krstic M. Right liver lobe/albumin ratio: Contribution to non-invasive assessment of portal hypertension. World J Gastroenterol. 2007;13:5331-5. 